\title{
The cyanobacterial nitrogen fixation paradox in natural
}

\section{waters [version 1; peer review: 2 approved]}

\author{
Hans Paerl (iD
}

Institute of Marine Sciences, University of North Carolina at Chapel Hill, Morehead City, NC, USA

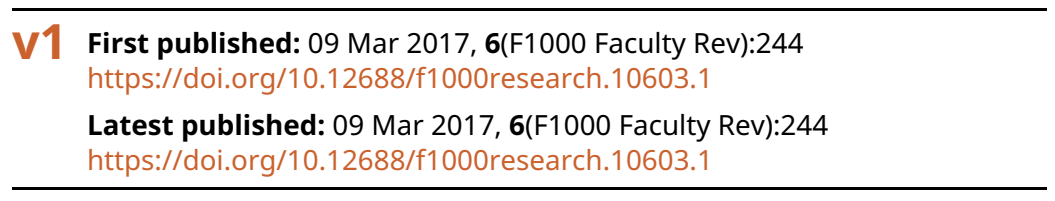

\section{Abstract}

Nitrogen fixation, the enzymatic conversion of atmospheric $\mathrm{N}\left(\mathrm{N}_{2}\right)$ to ammonia $\left(\mathrm{NH}_{3}\right)$, is a microbially mediated process by which "new" $\mathrm{N}$ is supplied to $\mathrm{N}$-deficient water bodies. Certain bloom-forming cyanobacterial species are capable of conducting $\mathrm{N}_{2}$ fixation; hence, they are able to circumvent $\mathrm{N}$ limitation in these waters. However, this anaerobic process is highly sensitive to oxygen, and since cyanobacteria produce oxygen in photosynthesis, they are faced with a paradoxical situation, where one critically important (for supporting growth) biochemical process is inhibited by another.

$\mathrm{N}_{2}$-fixing cyanobacterial taxa have developed an array of biochemical, morphological, and ecological adaptations to minimize the "oxygen problem"; however, none of these allows $\mathrm{N}_{2}$ fixation to function at a high enough efficiency so that it can supply $N$ needs at the ecosystem scale, where $\mathrm{N}$ losses via denitrification, burial, and advection often exceed the inputs of "new" $\mathrm{N}$ by $\mathrm{N}_{2}$ fixation. As a result, most marine and freshwater ecosystems exhibit chronic $\mathrm{N}$ limitation of primary production. Under conditions of perpetual $\mathrm{N}$ limitation, external inputs of $\mathrm{N}$ from human sources (agricultural, urban, and industrial) play a central role in determining ecosystem fertility and, in the case of $\mathrm{N}$ overenrichment, excessive primary production or eutrophication. This points to the importance of controlling external $\mathrm{N}$ inputs (in addition to traditional phosphorus controls) as a means of ensuring acceptable water quality and safe water supplies.

Nitrogen fixation, the enzymatic conversion of atmospheric $\mathrm{N}_{2}$ to ammonia $\left(\mathrm{NH}_{3}\right)$ is a microbially-mediated process by which "new" nitrogen is supplied to $\mathrm{N}$-deficient water bodies. Certain bloomforming cyanobacterial species are capable of conducting $\mathrm{N}_{2}$ fixation; hence they are able to circumvent nitrogen limitation in these waters. However, this anaerobic process is highly sensitive to oxygen, and since cyanobacteria produce oxygen in photosynthesis, they are faced with a paradoxical situation, where one critically-important (for supporting growth) biochemical process is inhibited by another. Diazotrophic cyanobacterial taxa have developed an array of

\author{
Open Peer Review \\ Approval Status \\ 1 \\ 2 \\ version 1 \\ 09 Mar 2017 \\ Faculty Reviews are review articles written by the \\ prestigious Members of Faculty Opinions. The \\ articles are commissioned and peer reviewed \\ before publication to ensure that the final, \\ published version is comprehensive and \\ accessible. The reviewers who approved the final \\ version are listed with their names and \\ affiliations. \\ 1. Justin Chaffin, Ohio State University, Put-in- \\ Bay, USA \\ 2. James Cotner, University of Minnesota, St. \\ Paul, USA \\ Any comments on the article can be found at the \\ end of the article.
}


biochemical, morphological and ecological adaptations to minimize the "oxygen problem"; however, none of these allows $\mathrm{N}_{2}$ fixation to function at a high enough efficiency so that it can supply $\mathrm{N}$ needs at the ecosystem scale, where $\mathrm{N}$ losses via denitrification, burial and advection often exceed the inputs of "new" $\mathrm{N}$ by $\mathrm{N}_{2}$ fixation.

As a result, most marine and freshwater ecosystems exhibit chronic $\mathrm{N}$ limitation of primary production. Under conditions of perpetual $\mathrm{N}$ limitation, external inputs of $\mathrm{N}$ from human sources (agricultural, urban, industrial) play a central role in determining ecosystem fertility and in the case of $\mathrm{N}$-overenrichment, excessive primary production, or eutrophication. This points to the importance of controlling external $\mathrm{N}$ inputs (in addition to traditional phosphorus controls) as a means of ensuring acceptable water quality and safe water supplies.

\section{Keywords}

cyanobacteria, nitrogen fixation, freshwater, marine

Corresponding author: Hans Paerl (hans_paerl@unc.edu)

Competing interests: The author declares that he has no competing interests.

Grant information: This work was partially supported by the National Science Foundation (DEB 9815495; CBET 0826819, 1230543; and Dimensions of Biodiversity 1240851).

The funders had no role in study design, data collection and analysis, decision to publish, or preparation of the manuscript.

Copyright: ( 2017 Paerl H. This is an open access article distributed under the terms of the Creative Commons Attribution License, which permits unrestricted use, distribution, and reproduction in any medium, provided the original work is properly cited. Data associated with the article are available under the terms of the Creative Commons Zero "No rights reserved" data waiver (CC0 1.0 Public domain dedication).

How to cite this article: Paerl $\mathrm{H}$. The cyanobacterial nitrogen fixation paradox in natural waters [version 1; peer review: 2 approved] F1000Research 2017, 6(F1000 Faculty Rev):244 https://doi.org/10.12688/f1000research.10603.1

First published: 09 Mar 2017, 6(F1000 Faculty Rev):244 https://doi.org/10.12688/f1000research.10603.1 
Nitrogen fixation, the biochemical conversion of "inert" atmospheric $\mathrm{N}\left(\mathrm{N}_{2}\right)$ to biologically available ammonia $\left(\mathrm{NH}_{3}\right)$, is a microbially mediated process of global significance because it provides "new" $\mathrm{N}$ to aquatic ecosystems in which biological production is often controlled by $\mathrm{N}$ availability ${ }^{1,2} \cdot \mathrm{N}_{2}$ fixation is an anaerobic process carried out by specific prokaryotes, including heterotrophic and chemolithotrophic bacteria and some cyanobacteria (blue-green algae) ${ }^{3}$. The process likely evolved during the oxygen $\left(\mathrm{O}_{2}\right)$-devoid Precambrian period some $2+$ billion years ago $^{4,5}$. Of the $\mathrm{N}_{2}$-fixing microbial taxa, the cyanobacteria are of particular biogeochemical and ecological interest because they were also the first $\mathrm{O}_{2}$-evolving photosynthetic organisms on Earth $^{6}$; their proliferation during this period is thought to be an evolutionary "milestone" because it led to the generation of an $\mathrm{O}_{2}$-rich atmosphere, a prerequisite for the evolution of $\mathrm{O}_{2}$-requiring fungi, bacteria, animals, and higher plant species on our planet ${ }^{6}$.

Ironically, the development of an $\mathrm{O}_{2}$-rich atmosphere, hydrosphere, and pedosphere constituted a formidable biochemical challenge for the cyanobacteria because, while they were capable of fixing $\mathrm{N}_{2}$, the process had to be confined to an $\mathrm{O}_{2}$-free microenvironment ${ }^{7}$. This requirement posed a serious dilemma, especially for aquatic cyanobacteria, because they require illuminated conditions in surface waters, but the high ambient $\mathrm{O}_{2}$ levels produced by photosynthesis in these waters also represents an environmental barrier to $\mathrm{O}_{2}$-sensitive $\mathrm{N}_{2}$ fixation. Over their long evolutionary history, cyanobacteria have developed biochemical and structural adaptations as well as biotic associations in order to optimize $\mathrm{N}_{2}$ fixation while relying on oxygenic photosynthesis to provide energy and organic carbon (C) compounds to support metabolism and growth. The adaptions include (1) confining $\mathrm{N}_{2}$ fixation to night-time when photosynthesis is "turned off", (2) forming colonies and aggregates to reduce illumination and form low- $\mathrm{O}_{2}$ "microzones", (3) participating as endosymbionts in biological associations, and (4), forming heterocysts (non-photosynthetic, $\mathrm{O}_{2}$-free cells) in some filamentous taxa, which allows $\mathrm{N}_{2}$ fixation to proceed while receiving photo-reductant and organic $\mathrm{C}$ through photosynthesis from adjacent cells ${ }^{8}$.

These are all remarkably clever adaptations to a modern-day oxic biosphere, which help circumvent the "O $\mathrm{O}_{2}$ problem" ${ }^{\text {. From }}$ an ecosystem perspective, they have allowed $\mathrm{N}_{2}$-fixing species to provide biologically available $\mathrm{N}$ from the vast reservoir of atmospheric $\mathrm{N}_{2}$. However, on the ecosystem scale, recent $\mathrm{N}$ budget analyses indicate that $\mathrm{N}_{2}$ fixation inputs fall far short of meeting ecosystem requirements when biologically available $\mathrm{N}$ inputs (from terrestrial and atmospheric sources) and losses (via denitrification, sedimentation and burial, and advection) are considered ${ }^{9-11}$. As a result, freshwater, estuarine, and marine systems are often chronically $\mathrm{N}$ deficient ${ }^{11-17}$. Pervasive $\mathrm{N}$ limitation has many implications for ecosystem function, especially when excessive external nutrient inputs lead to accelerating primary production (eutrophication), harmful algal blooms, and excessive $\mathrm{O}_{2}$ consumption (hypoxia). If chronic $\mathrm{N}$-limited conditions prevail in water bodies and $\mathrm{N}_{2}$ fixation cannot meet ecosystem $\mathrm{N}$ requirements, then external $\mathrm{N}$ inputs often supply $\mathrm{N}$ to support eutrophication and its unwanted symptoms. From a management perspective, this means that the growing global glut of $\mathrm{N}$ inputs from agricultural, urban, and industrial source ${ }^{14,18-20}$ needs to be controlled, in addition to the broadly accepted phosphorus (P) input constraints, in order to protect our waterways and water supplies.

Why does $\mathrm{N}_{2}$ fixation fall short of meeting ecosystem demands? Apparently, this process does not operate at sufficient rates in a modern-day, oxic world to compensate for losses via burial, export, and denitrification, even though it is protected and optimized by the various biological adaptations mentioned above. It is counteracted at larger scales by biogeochemical processes, such as denitrification, that run in the opposite direction $\left(\mathrm{NO}_{3} \rightarrow \mathrm{N}_{2}\right)$. The $\mathrm{N}_{2}$-fixing process is an energy-demanding one, requiring 16 ATP molecules to fix one molecule of $\mathrm{N}_{2}{ }^{3}$. In cyanobacteria, this energy demand has to be met by photosynthesis, while in non-photosynthetic bacteria, organic matter and redox reactions serve as energy sources ${ }^{3}$. In highly productive (eutrophic), turbid waters where cyanobacteria and bacteria thrive, the availability of photosynthetically active radiation (PAR: $400-700 \mathrm{~nm}$ ) is often restricted, causing a radiant energy deficit and suboptimal $\mathrm{N}_{2}$ fixation rates. Secondly, cyanobacteria taxa that dominate in eutrophic waters often accumulate as thick surface "blooms", in part to circumvent light limitation in subsurface waters ${ }^{11}$. High rates of photosynthesis in such blooms lead to $\mathrm{O}_{2}$ supersaturation, often in excess of $200 \%$ saturation $^{21}$. These ambient $\mathrm{O}_{2}$ levels inhibit $\mathrm{N}_{2}$ fixation in situ, even in heterocystous taxa ${ }^{22,23}$. Thirdly, $\mathrm{N}_{2}$ fixation requires high levels of $\mathrm{P}$ (to support the energetics, e.g. ATP formation and nucleic acid production) and metals, most prominently iron $(\mathrm{Fe})$, which is a co-factor in the enzyme complex nitrogenase ${ }^{3}$. In highly oxygenated surface waters, Fe occurs as the insoluble and biologically unavailable $\mathrm{Fe}^{3+}$ ion that may lead to Fe-limited conditions ${ }^{24}$. Lastly, wind-induced turbulence and vertical mixing can reduce $\mathrm{N}_{2}$ fixation potential by disrupting colonies and aggregates and enhancing inward diffusion of $\mathrm{O}_{2}$ (Figure 1$)^{25}$ and deepening the mixed layer, reducing light availability.

Thus, while $\mathrm{N}_{2}$ fixation converts inert $\mathrm{N}_{2}$ into biologically available $\mathrm{NH}_{3}$ to support aquatic fertility in a remarkable fashion, it faces multiple constraints and limitations in aquatic environments, especially in surface waters, which are often $\mathrm{N}$ limited. Geochemists, some limnologists, and a few oceanographers have assumed that as long as $\mathrm{P}$ and $\mathrm{Fe}$ are readily available, $\mathrm{N}_{2}$ fixation should make up for an $\mathrm{N}$ deficit, given the unlimited supply of $\mathrm{N}_{2}$ available ${ }^{26,27}$. However, this assumed linear stoichiometric relationship is not straightforward. Major environmental factors constrain this process, preventing it from functioning at optimal rates and supplying complete ecosystem $\mathrm{N}$ requirements ${ }^{8,11}$. As a result, much of the world's marine and freshwater environments remain chronically $\mathrm{N}$ deficient. In practical (management) terms, this limitation means that external inputs of $\mathrm{N}$ play a key role in providing adequate and excessive fertility (eutrophication) of many freshwater and most marine ecosystems ${ }^{11,15,16}$. Tremendous increases in anthropogenically generated bioavailable $\mathrm{N}$ in the form of synthetic (Haber process) fertilizers, agricultural, industrial, 


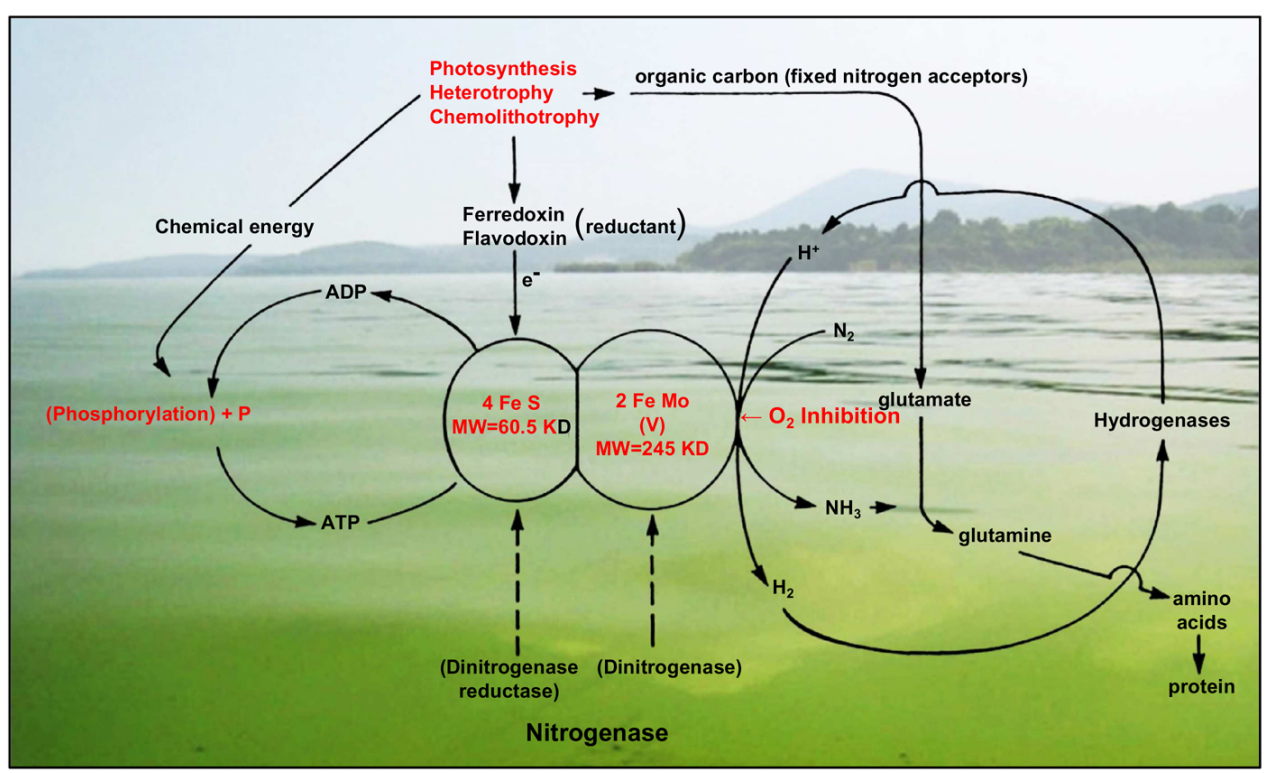

Figure 1. The nitrogen fixing process, as mediated by cyanobacteria (utilizing oxygenic photosynthesis as an energy and carbon source) as well as heterotrophic and chemolithotrophic microorganisms, in eutrophic surface waters. Potential environmental controls, including phosphorus (P) and iron (Fe) availability, energy sources, and dissolved oxygen inhibition, are shown in red. The background photo is of an $\mathrm{O}_{2}$-supersaturated (during daytime) cyanobacterial surface bloom in Lake Taihu, China. Photograph by H. Paerl.

and urban wastes, and $\mathrm{N}_{2}$ emissions (as both oxides and reduced forms of $\mathrm{N}$ ) far overshadow biological fixation of $\mathrm{N}_{2}$ in providing available $\mathrm{N}$ to receiving waters. Effective future management and protection of our fresh and marine waters will depend on the control of external inputs of both $\mathrm{N}$ and $\mathrm{P}^{11,27}$ instead of depending on the more traditional approach of controlling $\mathrm{P}$ inputs without $\mathrm{N}$ restrictions ${ }^{28}$.

\section{Competing interests}

The author declares that he has no competing interests.

\section{Grant information}

This work was partially supported by the National Science Foundation (DEB 9815495; CBET 0826819, 1230543; and Dimensions of Biodiversity 1240851).

The funders had no role in study design, data collection and analysis, decision to publish, or preparation of the manuscript.

\section{Acknowledgements}

I appreciate the helpful comments by my colleagues W. Gardner, M. McCarthy, and J.T. Scott and appreciate the technical assistance from A.R. Joyner.
1. Howarth RW, Marino R, Cole JJ: Nitrogen fixation in freshwater, estuarine, and marine ecosystems. 2. Biogeochemical controls. Limnol Oceanogr. 1988; 33(4 part 2): 688-701.

Publisher Full Text

2. Karl D, Michaels A, Bergman B, et al:: Dinitrogen fixation in the world's oceans. Biogeochemistry. 2002; 57(1): 47-98. Publisher Full Text

3. Postgate J: Nitrogen Fixation. Cambridge University Press, 1998. Reference Source

4. $\quad$ F Raymond J, Siefert JL, Staples CR, et al.: The natural history of nitrogen fixation. Mol Biol Evol. 2004; 21(3): 541-54.

PubMed Abstract | Publisher Full Text | F1000 Recommendation

5. Latysheva N, Junker VL, Palmer WJ, et al:: The evolution of nitrogen fixation in cyanobacteria. Bioinformatics. 2012; 28(5): 603-6.

PubMed Abstract | Publisher Full Text
6. Knoll AH: Life on a young planet: the first three billion years of evolution on earth. Princeton University Press, Princeton, 2003.

Reference Source

7. Gallon JR: Reconciling the incompatible: $\mathbf{N}_{2}$ fixation And $\mathrm{O}_{2}$. New Phytol. 1992 122(4): 571-609.

Publisher Full Text

8. Paerl HW: Physiological Ecology and Regulation of $\mathrm{N}_{2}$ Fixation in Natural Waters. In: Marshall KC editor. Adv Microb Ecol. Boston, MA: Springer US; 1990; 11: 305-344.

Publisher Full Text

9. Scott JT, McCarthy MJ: Nitrogen fixation may not balance the nitrogen pool in lakes over timescales relevant to eutrophication management. Limnol Oceanogr. 2010; 55(3): 1265-70. Publisher Full Text

10. F Grantz EM, Haggard BE, Scott JT: Stoichiometric imbalance in rates of 
nitrogen and phosphorus retention, storage, and recycling can perpetuate nitrogen deficiency in highly-productive reservoirs. Limnol Oceanogr. 2014; 59(6): 2203-16.

Publisher Full Text | F1000 Recommendation

11. Paerl HW, Scott JT, McCarthy MJ, et al:: It Takes Two to Tango: When and Where Dual Nutrient (N \& P) Reductions Are Needed to Protect Lakes and Downstream Ecosystems. Environ Sci Technol. 2016. PubMed Abstract | Publisher Full Text

12. Dugdale RC: Nutrient limitation in the sea: dynamics, identification, and significance. Limnol Oceanogr. 1967; 12(4): 685-95. Publisher Full Text

13. F Elser JJ, Bracken ME, Cleland EE, et al:: Global analysis of nitrogen and phosphorus limitation of primary producers in freshwater, marine and terrestrial ecosystems. Ecol Lett. 2007; 10(12): 1135-42. PubMed Abstract | Publisher Full Text | F1000 Recommendation

14. Paerl HW, Piehler MF: Nitrogen and Marine Eutrophication. In DG Capone, M. Mulholland and E. Carpenter (Eds.), Nitrogen in the Marine Environment. Academic Press, Orlando. 2008; 2: 529-567. Publisher Full Text

15. Conley DJ, Paerl HW, Howarth RW, et al:: Ecology. Controlling eutrophication: nitrogen and phosphorus. Science. 2009; 323(5917): 1014-5. PubMed Abstract | Publisher Full Text

16. Lewis WM, Wurtsbaugh WA, Paerl HW: Rationale for control of anthropogenic nitrogen and phosphorus to reduce eutrophication of inland waters. Environ Sci Technol. 2011; 45(24): 10300-5. PubMed Abstract | Publisher Full Text

17. F Dodds W, Smith V: Nitrogen, phosphorus, and eutrophication in streams. Inland Waters. 2016; 6: 155-64.

Publisher Full Text | F1000 Recommendation

18. Galloway JN, Cowling EB, Seitzinger SP, et al:: Reactive Nitrogen: Too Much of a Good Thing? Ambio. 2002; 31(2): 60-3. PubMed Abstract | Publisher Full Text

19. US EPA: Reactive Nitrogen in the United States: An Analysis of Inputs, Flows,
Consequences, and Management Options. A Report of the EPA Science Advisory Board. EPA-SAB-11-013. Unites States of America Environmental Protection Agency: Washington, DC, 2011.

Reference Source

20. Glibert PM, Maranger R, Sobota DJ: The Haber Bosch-harmful algal bloom (HBHAB) link. Environ Res Lett. 2014; 9(10): 105001. Publisher Full Text

21. Paerl HW, Webb KL, Weibe WJ: Nitrogen fixation in waters. In WJ Broughton (ed.), The Ecology of Nitrogen Fixation. Oxford Univ Press, Oxford, 1981; 193-241.

22. Paerl HW, Kellar PE: Nitrogen-fixing anabaena: physiological adaptations instrumental in maintaining surface blooms. Science. 1979; 204(4393): 620-2. PubMed Abstract | Publisher Full Text

23. Kellar PE, Paerl HW: Physiological adaptations in response to environmental stress during an $\mathbf{N}_{2}$-fixing Anabaena bloom. Appl Environ Microbiol. 1980; 40(3): 587-595.

PubMed Abstract | Free Full Text

24. Hyenstrand P, Rydin E, Gunnerhed M: Response of pelagic cyanobacteria to iron additions--enclosure experiments from Lake Erken. J Plankton Res. 2000; 22(6): 1113-26. Publisher Full Text

25. Moisander $\mathrm{PH}$, Hench JL, Kononen $\mathrm{K}$, et al.: Small-scale shear effects on heterocystous cyanobacteria. Limnol Oceanogr. 2002; 47(1): 108-19. Publisher Full Text

26. Tyrrell $\mathrm{T}$ : The relative influences of nitrogen and phosphorus on oceanic primary production. Nature. 1999; 400: $525-31$. Publisher Full Text

27. Paerl HW, Otten TG: Duelling 'CyanoHABs': unravelling the environmental drivers controlling dominance and succession among diazotrophic and non- $\mathrm{N}_{2}$-fixing harmful cyanobacteria. Environ Microbiol. 2016; 18(2): 316-24. PubMed Abstract | Publisher Full Text

28. F Schindler DW, Hecky RE, Findlay DL, et al:: Eutrophication of lakes cannot be controlled by reducing nitrogen input: results of a 37-year wholeecosystem experiment. Proc Natl Acad Sci U S A. 2008; 105(32): 11254-8. PubMed Abstract | Publisher Full Text | Free Full Text | F1000 Recommendation 


\section{Open Peer Review}

\section{Current Peer Review Status:}

\section{Editorial Note on the Review Process}

Faculty Reviews are review articles written by the prestigious Members of Faculty Opinions. The articles are commissioned and peer reviewed before publication to ensure that the final, published version is comprehensive and accessible. The reviewers who approved the final version are listed with their names and affiliations.

\section{The reviewers who approved this article are:}

\section{Version 1}

\section{James Cotner}

University of Minnesota, St. Paul, MN, 55108, USA

Competing Interests: No competing interests were disclosed.

\section{Justin Chaffin}

Stone Laboratory, Ohio State University, Put-in-Bay, OH, USA

Competing Interests: No competing interests were disclosed.

The benefits of publishing with F1000Research:

- Your article is published within days, with no editorial bias

- You can publish traditional articles, null/negative results, case reports, data notes and more

- The peer review process is transparent and collaborative

- Your article is indexed in PubMed after passing peer review

- Dedicated customer support at every stage

For pre-submission enquiries, contact research@f1000.com 